Check for updates

Cite this: RSC Adv., 2019, 9, 5501

Received 5th January 2019

Accepted 4th February 2019

DOI: 10.1039/c9ra00097f

rsc.li/rsc-advances

\section{Superparamagnetic nanoparticle-catalyzed coupling of 2-amino pyridines/pyrimidines with trans-chalcones $\uparrow$}

\author{
Oanh T. K. Nguyen, Pha T. Ha, Ha V. Dang, Yen H. Vo, Tung T. Nguyen, Nhan T. H. Le* \\ and Nam T. S. Phan (iD)*
}

An aerobic coupling of 2-aminopyrimidines or 2-aminopyridines with trans-chalcones to afford aroylimidazo[1,2-a]pyrimidines and aroylimidazo[1,2-a]pyridines is reported. Reactions proceed in the presence of $\mathrm{CuFe}_{2} \mathrm{O}_{4}$ superparamagnetic nanoparticle catalyst, two equivalents of iodine, oxygen oxidant, and 1,4-dioxane solvent. The catalyst is superior to many common copper or iron complexes. Copper ferrite could be easily separated by magnetic decantation and reused up to 5 times without a major loss of activity. The method described here marks a rare example of using a simple, heterogeneous catalyst for synthesis of fused heterocycles. To our best knowledge, aroylimidazo[1,2-a] pyrimidines and aroylimidazo[1,2-a]pyridines were not previously synthesized using this protocol.

\section{Introduction}

Imidazo[1,2- $a]$ pyridines find uses as carbene-typed ligands, organic materials, and in commercial drugs. ${ }^{1}$ Derivatization of imidazo[1,2-a]pyridines has recently emerged with regards to simple, efficient methods. ${ }^{2}$ A few prototypical derivatives such as aroylimidazo[1,2-a]pyridines are attracting attention of synthetic chemists due to potent bioactivities. ${ }^{1}$ Common methods are mostly focusing on coupling of $\alpha, \beta$-unsaturated ketones or ketimines with 2-aminopyridines, since the starting materials are readily available or easily obtained. ${ }^{3}$ Notably, a few reports use prefunctionalized starting materials, thus limiting the practicality. ${ }^{4}$ Moreover, the use of strong bases, harsh conditions, ligand requirement, and nonreusable catalysts is notoriously challenging with regard to green chemistry. Thus, methods using simple reagents in combination with reusable catalysts for the synthesis of aroylimidazo[1,2-a]pyridines or aroylimidazo[1,2-a]pyrimidines still remain to be developed.

Nanocatalysis comprises methods of using nanoparticles to facilitate chemical transformations. Over the last two decades, significant efforts have led to the use of many nanoparticles in synthetic chemistry, bridging the gap between traditional heterogeneous and homogeneous catalysis. ${ }^{5}$ The catalytic activity of nanocatalysts is directly referred to surface areas of the particles; thus, most active sites would be readily accessible to reactants at nanometer dimension. Practicality of the

Faculty of Chemical Engineering, HCMC University of Technology, VNU-HCM, 268 Ly Thuong Kiet, District 10, Ho Chi Minh City, Vietnam.E-mail: lthnhan@hcmut.edu.vn; ptsnam@hcmut.edu.vn

$\dagger$ Electronic supplementary information (ESI) available. See DOI: 10.1039/c9ra00097f nanoparticles, however, suffers from challenges of separation and recovery. ${ }^{5 a}$ Using superparamagnetic particles in catalysis would be a prominent solution as the nanoparticles could be recovered by magnetic decantation instead of filtration or centrifugation. Consequently, loss of the catalyst would be thwarted. Many reports of using superparamagnetic catalysts for organic reactions are known. ${ }^{6}$ Due to uniquely high activity of copper catalysis for cross couplings, the use of magnetic copper-based catalysts is exponentially growing.7 A couple of seminal reports by Glorius and co-workers emphasize a prominent role of copper impregnated on magnetite $\left(\mathrm{CuO} / \mathrm{Fe}_{3} \mathrm{O}_{4}\right)$ catalyst for $\mathrm{C}-\mathrm{H}$ arylation. ${ }^{7}$ As our continuous interest in leveraging catalytic activity of copper ferrite nanoparticles, ${ }^{8}$ we report here a method for $\mathrm{CuFe}_{2} \mathrm{O}_{4}$-catalyzed coupling of 2amino pyridines/pyrimidines with trans-chalcones to synthesize aroylimidazo[1,2-a]pyridines/aroylimidazo[1,2-a]pyrimidines (Scheme 1). The conditions allow a mild and straightforward route to prepare fused $\mathrm{N}$-heterocycles in the presence of a heterogeneous catalyst, which is still limited in the literature.

\section{Experimental section}

$\mathrm{CuFe}_{2} \mathrm{O}_{4}$ nanoparticles were purchased from Sigma-Aldrich and used as received. A typical reaction follows the general procedure: to a pressurized vial was charged trans-chalcone $(62 \mathrm{mg}$, $0.3 \mathrm{mmol}$ ), 2-aminopyrimidine ( $48 \mathrm{mg}, 0.5 \mathrm{mmol}), \mathrm{I}_{2}(254 \mathrm{mg}$, $0.6 \mathrm{mmol}), \mathrm{CuFe}_{2} \mathrm{O}_{4}$, diphenyl ether $(51 \mathrm{mg}, 0.3 \mathrm{mmol})$ internal standard, and 1,4-dioxane $(2.5 \mathrm{~mL})$. The vial was heated at $140{ }^{\circ} \mathrm{C}$ for $7 \mathrm{~h}$ under an oxygen atmosphere. The reaction progress was monitored by withdrawing an aliquot of the reaction mixture and quenching with $\mathrm{Na}_{2} \mathrm{~S}_{2} \mathrm{O}_{3}$ solution $(10 \% \mathrm{v} /$ 
<smiles>[R7]C=CC=[V]</smiles><smiles>[R2]c1ccccc1/C=C/C(=O)c1ccccc1</smiles>

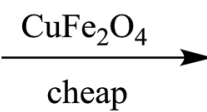

recoverable<smiles>[R]C=CN1C=C([R])C=[X]C1=C(C(=O)c1ccccc1)c1nc2ncccc2[R]1[R]</smiles>

Scheme 1 Heterogeneous copper-catalyzed coupling of 2-amino pyridines/pyrimidines with chalcones.

$\mathrm{v}, 1 \mathrm{~mL}$ ). Organic compounds then were extracted with ethyl acetate $(2 \mathrm{~mL} \times 2)$. Combined organic phases were dried over $\mathrm{Na}_{2} \mathrm{SO}_{4}$, filtered, and analyzed by gas chromatography.

To test the reusability of the superparamagnetic nanoparticles, the copper-iron oxide $\mathrm{CuFe}_{2} \mathrm{O}_{4}(8 \mathrm{mg}, 30 \mu \mathrm{mol})$ was added to a mixture of trans-chalcone $(62 \mathrm{mg}, 0.3 \mathrm{mmol}), 2$ aminopyrimidine ( $48 \mathrm{mg}, 0.5 \mathrm{mmol}), \mathrm{I}_{2}(254 \mathrm{mg}, 0.6 \mathrm{mmol}$ ), and 1,4-dioxane $(2.5 \mathrm{~mL})$. The mixture was heated at $140{ }^{\circ} \mathrm{C}$ for $7 \mathrm{~h}$ under an oxygen atmosphere. The solid catalyst was collected by magnetic decantation after reaction was complete. The recovered superparamagnetic $\mathrm{CuFe}_{2} \mathrm{O}_{4}$ nanoparticles were carefully washed with ethyl acetate $(10 \mathrm{~mL})$, ethanol $(10 \mathrm{~mL})$, and acetone $(10 \mathrm{~mL})$ to remove impurities. The resulting solids were then heated at $120^{\circ} \mathrm{C}$ under strong vacuum for $6 \mathrm{~h}$. The catalyst was then used for a new catalytic reaction using the procedure of the first run.

Yields presented in Table 2 are isolated yields. All of the entries were done using the following procedure unless notice:

Table 1 Optimization conditions<smiles>Nc1ncccn1</smiles>

1

\begin{tabular}{|c|c|c|c|c|c|}
\hline 1 & $\mathrm{CuFe}_{2} \mathrm{O}_{4}$ & 60 & 1.6 & 1,4-Dioxane & 7 \\
\hline 3 & $\mathrm{CuFe}_{2} \mathrm{O}_{4}$ & 140 & 1.6 & 1,4-Dioxane & $84,81^{b}$ \\
\hline 4 & $\mathrm{CuFe}_{2} \mathrm{O}_{4}$ & 140 & 1 & 1,4-Dioxane & 70 \\
\hline 5 & $\mathrm{CuFe}_{2} \mathrm{O}_{4}$ & 140 & 2.3 & 1,4-Dioxane & 63 \\
\hline 8 & $\mathrm{CuFe}_{2} \mathrm{O}_{4}$ & 140 & 1.6 & Chlorobenzene & 70 \\
\hline $9^{c}$ & $\mathrm{CuFe}_{2} \mathrm{O}_{4}$ & 140 & 1.6 & 1,4-Dioxane & 0 \\
\hline $10^{d}$ & $\mathrm{CuFe}_{2} \mathrm{O}_{4}$ & 140 & 1.6 & 1,4-Dioxane & 49 \\
\hline $11^{e}$ & $\mathrm{CuFe}_{2} \mathrm{O}_{4}$ & 140 & 1.6 & 1,4-Dioxane & 15 \\
\hline $12^{f}$ & $\mathrm{CuFe}_{2} \mathrm{O}_{4}$ & 140 & 1.6 & 1,4-Dioxane & 56 \\
\hline 13 & - & 140 & 1.6 & 1,4-Dioxane & 15 \\
\hline 18 & $\mathrm{FeCl}_{2}$ & 140 & 1.6 & 1,4-Dioxane & 67 \\
\hline 19 & $\mathrm{FeCl}_{3}$ & 140 & 1.6 & 1,4-Dioxane & 41 \\
\hline 20 & $\mathrm{Fe}_{2} \mathrm{O}_{3}{ }^{h}$ & 140 & 1.6 & 1,4-Dioxane & 21 \\
\hline 21 & $\mathrm{CuO}^{h}$ & 140 & 1.6 & 1,4-Dioxane & 29 \\
\hline
\end{tabular}

${ }^{a}$ Trans-Chalcone $(0.3 \mathrm{mmol}), \mathrm{CuFe}_{2} \mathrm{O}_{4}(30 \mu \mathrm{mol}, 10 \mathrm{~mol} \%), \mathrm{I}_{2}(0.6 \mathrm{mmol})$, solvent $(2.5 \mathrm{~mL})$, under $\mathrm{O}_{2}, 7 \mathrm{~h}$. Yields are GC yields using diphenyl ether internal standard. ${ }^{b}$ Isolated yield. ${ }^{c}$ No $\mathrm{I}_{2} \cdot{ }^{d} \mathrm{I}_{2}(0.45 \mathrm{mmol}) .{ }^{e} \mathrm{I}_{2}(0.3 \mathrm{mmol}) .{ }^{f} \mathrm{CuFe}_{2} \mathrm{O}_{4}(22.5 \mu \mathrm{mol}, 7.5 \mathrm{~mol} \%) .{ }^{g}$ Under argon. ${ }^{h}$ Nano oxides. 
View Article Online

Paper

RSC Advances

Table 2 Scope of aroylimidazo[1,2-a]pyrimidine/aroylimidazo[1,2-a]pyridine synthesis ${ }^{a}$<smiles>[X]c1cccc(/C=C/C(=O)c2ccccc2[R])c1</smiles>

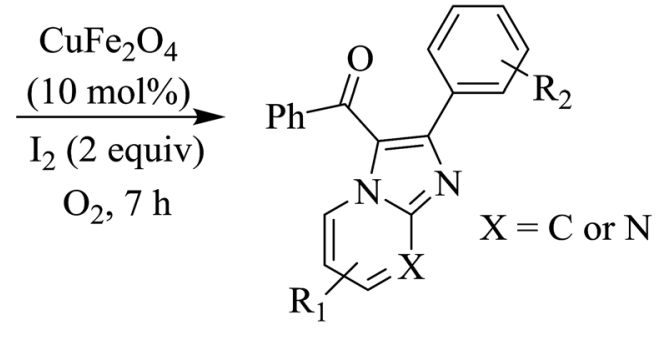

\begin{tabular}{llll}
\hline Entry $\quad$ Chalcones & 2-Aminopyrimi-dines or 2-aminopyridines & Products & Yield $^{b}, \%$ \\
\hline
\end{tabular}

1<smiles>O=C(/C=C/c1ccc(Cl)cc1)c1ccccc1</smiles><smiles>Nc1ncccn1</smiles><smiles>O=C(c1ccccc1)c1c(-c2ccc(Cl)cc2)nc2ncccn12</smiles>

76

2<smiles>Nc1ccccn1</smiles><smiles>O=C(c1ccccc1)c1c(-c2ccccc2)nc2ccccn12</smiles>

65

3<smiles>O=C(/C=C/c1ccc(Cl)cc1)c1ccccc1</smiles><smiles>Nc1ccccn1</smiles><smiles>O=C(c1ccccc1)c1c(-c2ccc(Cl)cc2)nc2ccccn12</smiles>

67

4<smiles>COc1ccc(/C=C/C(=O)c2ccccc2)cc1</smiles><smiles>Nc1ccccn1</smiles><smiles>COc1ccc(-c2nc3ccccn3c2C(=O)c2ccccc2)cc1</smiles>

68

5<smiles>Cc1ccnc(N)c1</smiles><smiles>Cc1ccn2c(C(=O)c3ccccc3)c(-c3ccccc3)nc2c1</smiles>

75

This journal is (c) The Royal Society of Chemistry 2019

RSC Adv., 2019, 9, 5501-5511 | 5503 
Table 2 (Contd.)<smiles>[R]c1cccc(/C=C/C(=O)c2ccccc2[R2])c1</smiles>

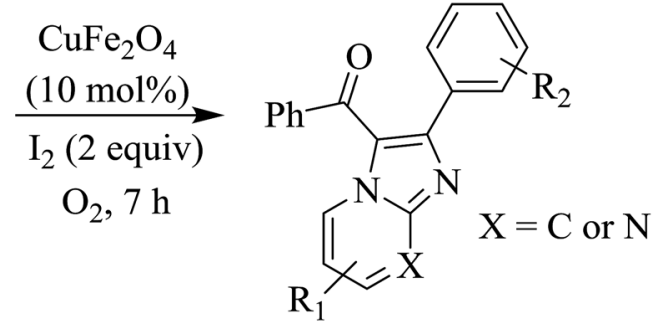

Entry Chalcones 2-Aminopyrimi-dines or 2-aminopyridines

Products

Yield $^{b}, \%$

6<smiles>O=C(/C=C/c1ccc(Cl)cc1)c1ccccc1</smiles>

7<smiles>COc1ccc(/C=C/C(=O)c2ccccc2)cc1</smiles>

8<smiles>O=C(/C=C/c1ccccc1)c1ccccc1</smiles><smiles>COc1ccc(/C=C/C(=O)c2ccccc2)cc1</smiles><smiles>Cc1ccnc(N)c1</smiles><smiles>Cc1ccnc(N)c1</smiles><smiles>Cc1ccc(N)nc1</smiles><smiles>Cc1ccc(N)nc1</smiles><smiles>Cc1ccn2c(C(=O)c3ccccc3)c(-c3ccc(Cl)cc3)nc2c1</smiles>

69<smiles>COc1ccc(-c2nc3cc(C)ccn3c2C(=O)c2ccccc2)cc1</smiles>

70<smiles>Cc1ccc2nc(-c3ccccc3)c(C(=O)c3ccccc3)n2c1</smiles>

71<smiles>COc1ccc(-c2nc3ccc(C)cn3c2C(=O)c2ccccc2)cc1</smiles> 
View Article Online

Paper

RSC Advances

Table 2 (Contd.)

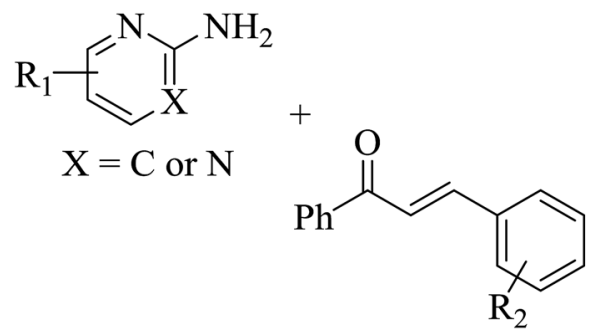

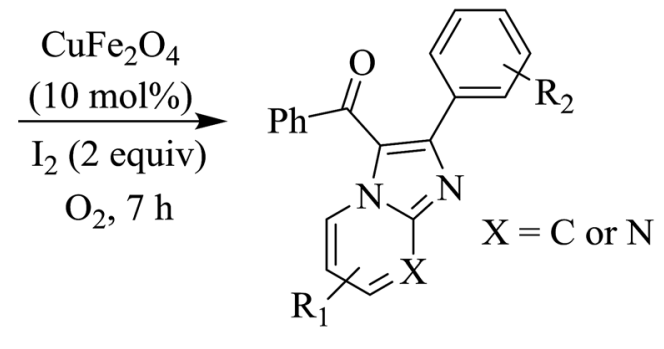

\begin{tabular}{llll}
\hline Entry $\quad$ Chalcones & 2-Aminopyrimi-dines or 2-aminopyridines & Products & Yield $^{b}, \%$ \\
\hline
\end{tabular}

10<smiles>O=C(/C=C/c1ccc(Cl)cc1)c1ccccc1</smiles><smiles>Cc1ccc(N)nc1</smiles><smiles>Cc1ccc2nc(-c3ccc(Cl)cc3)c(C(=O)c3ccccc3)n2c1</smiles>

75

11<smiles>O=C(/C=C/c1ccc(Cl)cc1)c1ccccc1</smiles><smiles>Cc1cccnc1N</smiles><smiles>Cc1cccn2c(C(=O)c3ccccc3)c(-c3ccc(Cl)cc3)nc12</smiles>

73

12<smiles>Nc1ccc(Cl)cn1</smiles><smiles>O=C(c1ccccc1)c1c(-c2ccccc2)nc2ccc(Cl)cn12</smiles>

13<smiles>O=C(/C=C/c1ccccc1)c1ccccc1</smiles><smiles>Nc1ccc(Cl)cn1</smiles><smiles>COc1ccc(-c2nc3ccc(Cl)cn3c2C(=O)c2ccccc2)cc1</smiles>

68

This journal is (C) The Royal Society of Chemistry 2019

RSC Adv., 2019, 9, 5501-5511 | 5505 
Table 2 (Contd.)<smiles>[R]c1cccc(/C=C/C(=O)c2ccccc2)c1[R]</smiles>

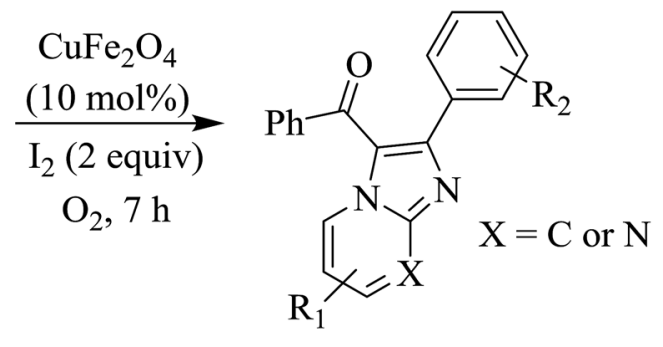

Entry Chalcones 2-Aminopyrimi-dines or 2-aminopyridines

Products

Yield $^{b}, \%$

14<smiles>COc1ccc(/C=C/C(=O)c2ccccc2)cc1</smiles>

15<smiles>O=C(/C=C/c1ccccc1)c1ccccc1</smiles>

16<smiles>O=C(/C=C/c1ccccc1)c1ccc(Br)cc1</smiles>

17<smiles>O=C(/C=C/c1ccccc1)c1ccc([N+](=O)[O-])cc1</smiles>

18<smiles>COc1ccc(C(=O)/C=C/c2ccccc2)cc1</smiles><smiles>Nc1cccc(Br)n1</smiles><smiles>COC(=O)c1ccnc(N)c1</smiles><smiles>Nc1ccccn1</smiles><smiles>Nc1ccccn1</smiles><smiles>Nc1ccccn1</smiles><smiles>COc1ccc(-c2nc3cccc(Br)n3c2C(=O)c2ccccc2)cc1</smiles>

65

65

59

18<smiles>Cn1ccccc1=N</smiles><smiles>COc1ccc(C(=O)c2c(-c3ccccc3)nc3ccccn23)cc1</smiles> 


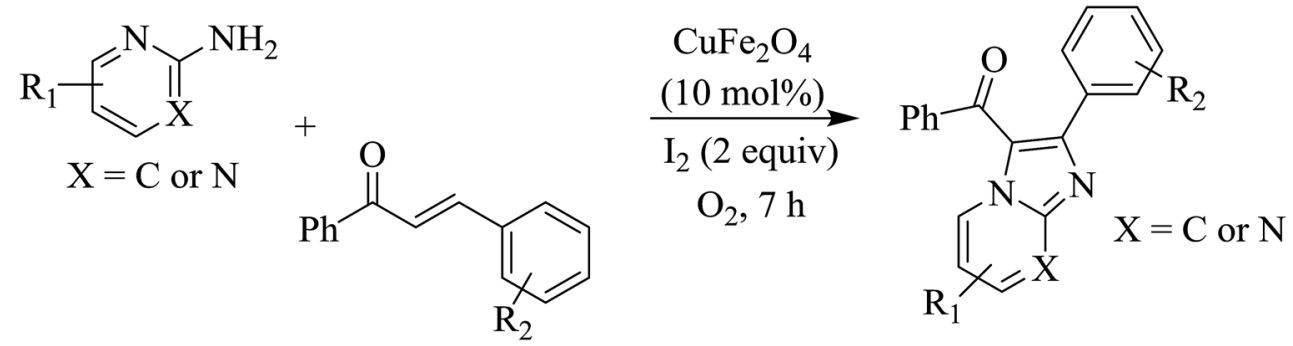

\section{Entry Chalcones} 2-Aminopyrimi-dines or 2-aminopyridines

Products

Yield $^{b}, \%$

$19^{b}$<smiles>O=[N+]([O-])C=Cc1ccccc1</smiles><smiles>Nc1ccccn1</smiles><smiles>O=[N+]([O-])c1c(-c2ccccc2)nc2ccccn12</smiles>

63 ${ }^{a}$ Trans-Chalcones $(0.3 \mathrm{mmol}), 2$-aminopyridines or 2 -aminopyrimidine $(1.6$ equiv. $), \mathrm{I}_{2}$ (2 equiv.), 1,4 -dioxane $(2.5 \mathrm{~mL}), 140{ }^{\circ} \mathrm{C}, 7 \mathrm{~h} . \mathrm{Yields}$ are
isolated yields. Please see the ESI for details. ${ }^{b}$ 2-Aminopyridine $(0.5 \mathrm{mmol})$.

to a pressurized vial was charged chalcone ( $0.3 \mathrm{mmol}), 2$-aminopyrimidine or 2-aminopyrimidine $(0.5 \mathrm{mmol}), \mathrm{I}_{2}(254 \mathrm{mg}, 0.6$ $\mathrm{mmol}), \mathrm{CuFe}_{2} \mathrm{O}_{4}(30 \mu \mathrm{mol}, 8 \mathrm{mg})$, and 1,4-dioxane (2.5 mL). In Scheme 3, the amount of reactants and reagents were used as: dibenzylideneacetone $(0.4 \mathrm{mmol}, 94 \mathrm{mg}), 2$-aminopyridine (0.8 mmol, $75 \mathrm{mg}), \mathrm{CuFe}_{2} \mathrm{O}_{4}(40 \mu \mathrm{mol}, 10 \mathrm{mg}), \mathrm{I}_{2}(0.8 \mathrm{mmol}, 203$ $\mathrm{mg}), 1,4$-dioxane $(3 \mathrm{~mL})$. The vial was heated at $140{ }^{\circ} \mathrm{C}$ for $7 \mathrm{~h}$ under an oxygen atmosphere. The reaction progress was monitored by withdrawing an aliquot of the reaction mixture and quenching with $\mathrm{Na}_{2} \mathrm{~S}_{2} \mathrm{O}_{3}$ solution $(10 \% \mathrm{v} / \mathrm{v}, 1 \mathrm{~mL})$. Organic compounds then were extracted with ethyl acetate $(2 \mathrm{~mL} \times 2)$. Combined organic phases were dried over $\mathrm{Na}_{2} \mathrm{SO}_{4}$, filtered, and concentrated. Purification by column chromatography afforded desire products. Characterization of the compounds used ${ }^{1} \mathrm{H}$, ${ }^{13} \mathrm{C}$, and ${ }^{19} \mathrm{~F}$ spectra, which were recorded on Bruker AV 500, JEOL EC-400, or JEOL EC-600 spectrometers using residual solvent peaks as references.

\section{Results and discussion}

The cyclization of trans-chalcone and 2-aminopyrimidine was investigated with respect to reaction temperature, amount of 2aminopyrimidine, solvents, amount of iodine, catalyst concentration, and different copper or iron salts (Table 1). Only trace amount of the product 1 was obtained if the reaction was run at $60{ }^{\circ} \mathrm{C}$ (entry 1). Increasing temperature resulted in better yield (entries 2 and 3). At $140{ }^{\circ} \mathrm{C}$, a complete conversion of transchalcone was observed. 2-Aminopyrimidine should be slightly excess to afford good yield of 1 (entry 4). Interestingly, using more than two equivalents of 2-aminopyrimidine lowered the yield (entry 5). Strongly coordinated solvents such as DMF or DMSO are not suitable for this reaction (entries 6 and 7), while chlorobenzene is inferior to 1,4-dioxane (entry 8). No product was obtained if $I_{2}$ was omitted (entry 9). Using less than 2 equivalents of $I_{2}$ plummeted the yield of 1 (entries 10 and 11). Low yield was also obtained if the amount of $\mathrm{CuFe}_{2} \mathrm{O}_{4}$ was<smiles>Nc1ccccn1</smiles><smiles>[2H]C([2H])(C)OC(=O)c1ccc(/C=C/C(=O)c2c(-c3ccccc3)nc3ccccn23)cc1</smiles>

$2,60 \%$

Scheme 2 Copper ferrite-catalyzed coupling of dibenzylideneacetone and 2-aminopyridine. 


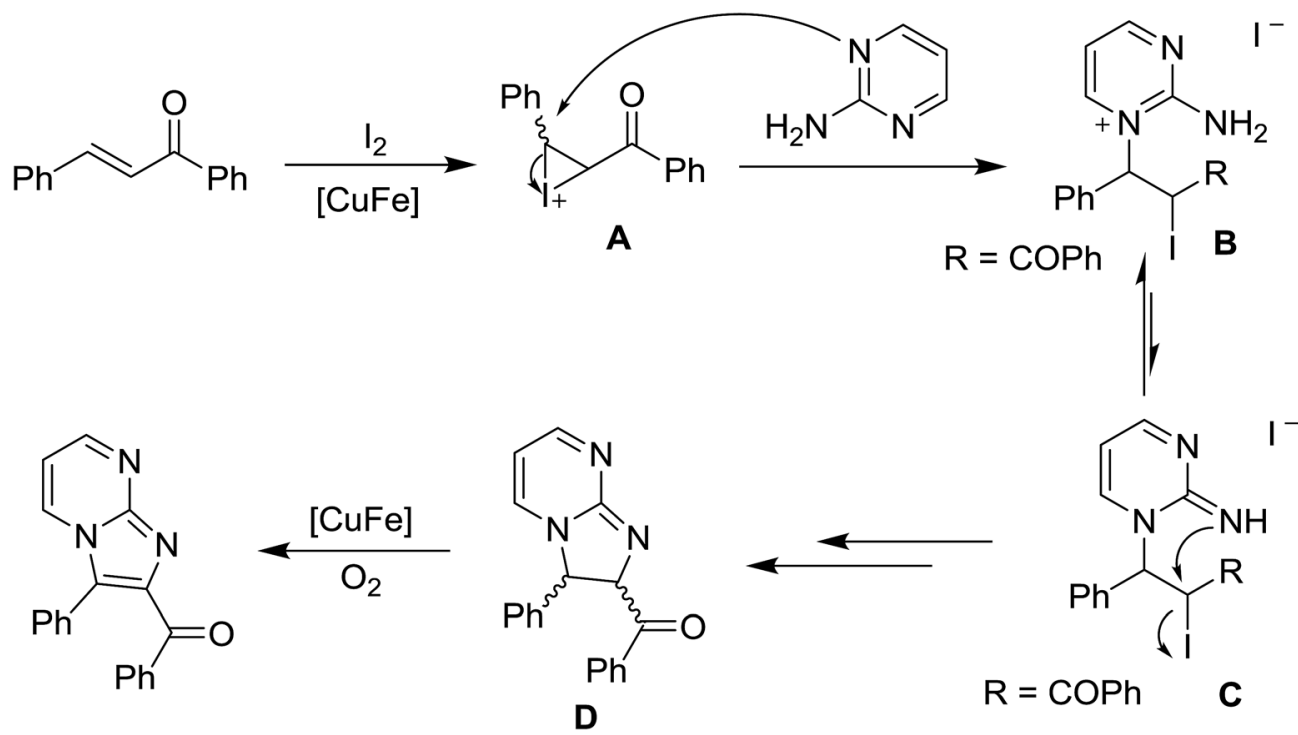

Scheme 3 Plausible mechanism.

decreased (entry 12). Running the reaction in the absence of copper ferrite gave 1 in $15 \%$ yield (entry 13). The coupling was not successful under argon atmosphere (entry 14), proving that oxygen oxidant is crucial. Such a copper-mediated aerobic transformation is known. ${ }^{3 a, 3 e, 3 f}$

To highlight the prominent role of $\mathrm{CuFe}_{2} \mathrm{O}_{4}$ for the coupling, uses of other heterogeneous or commercial catalysts were examined. The reaction is tolerant of many copper and iron salts, albeit at lower yields (entries 15-21, Table 1). Interestingly, nanoparticles of copper or iron oxides gave product 1 in extremely low yields (entries 20 and 21). Although we could not rationalize the reason for this phenomenon, the results emphasize the synergistic effect of copper-iron cluster. It should be noted that, Glorius and co-workers, when studying the copper ferrite-catalyzed, direct $\mathrm{C}-\mathrm{H}$ arylation of heteroarenes, also observed inexplicably low yields when copper and iron oxides were solely used. ${ }^{7 a}$

Reaction scope is presented in Table 2. Reaction of 2-aminopyrimidine with a chloro derivative of trans-chalcone gave the product in $76 \%$ yield (entry 1 ). The conditions are also used to couple 2-aminopyridines with trans-chalcones (entries 2-19). Good yields are obtained regardless of electronic properties of trans-chalcones (entries 2-14). The reaction tolerates methyl, chloro, bromo, and methoxy groups. That halogenated 2-aminopyridines successfully coupled with trans-chalcone (entries 12-14) is helpful since the products could be modified via crosscoupling reactions. A 2-aminopyridine bearing carboxylate functionality gave the product in $65 \%$ yield (entry 15). With respect to the substituents on the keto moiety of chalcones, electron donating groups were superior to electron withdrawing groups (entries 16-18). The conditions are applied for synthesis of a 3-nitroimidazo[1,2-a]pyridine derivative in moderate yield (entry 19).

To confirm whether double annulation is possible or not, a highly conjugated chalcone such as dibenzylideneacetone was used to couple with 2-aminopyridine under standard conditions. The reaction only afforded $60 \%$ yield of a monocoupling product 2 even in the presence of two equivalents of 2-aminopyridine (Scheme 2). Interestingly, a similar result was observed by Hajra and co-workers when a copperphenanthroline system was used for the reaction. ${ }^{3 a}$

A possible mechanism to obtain 3-benzoylimidazo[1,2-a] pyrimidine is presented in Scheme 3 . We speculated that the reaction may proceed through the formation of some $\alpha$-iodo ketone-typed compounds $(\mathbf{A} \rightarrow \mathbf{B} \leftrightarrow \mathbf{C}) .^{3 \boldsymbol{d}, 3 g}$ The copper iron oxide could increase the electrophilicity of the carbon-carbon double bond through binding, thus helping the first nucleophilic substitution. Oxidation of the $\alpha, \beta$ carbon-carbon single bond to form the enone-typed compound may also be facilitated by $\mathrm{CuFe}_{2} \mathrm{O}_{4}$ species in the presence of oxygen oxidant. Such a copper-mediated aerobic oxidation has been reported by Hajra and Kumar., ${ }^{3 a, 3 e, 3 f}$ The rate-determining step is perhaps the oxidation of $\mathrm{C}-\mathrm{C}$ bond, since low yields were obtained in the case of electron-poor ketones. A possibility of involving iodinefree cyclocuprate species in the mechanism could be ruled out under our conditions, ${ }^{3 a}$ because running the reaction in the absence of iodine did not afford the desire product.

A hot filtration test was carried out to confirm the heterogeneity of the catalyst, since the formation of product 1 could be possibly attributed to soluble active species. ${ }^{7 a}$ The reaction of 2aminopyrimidine and trans-chalcone proceeded in the presence of $10 \mathrm{~mol} \% \mathrm{CuFe}_{2} \mathrm{O}_{4}$, oxygen oxidant, and 1,4-dioxane solvent at $140{ }^{\circ} \mathrm{C}$ for $7 \mathrm{~h}$. After two hours, $\mathrm{CuFe}_{2} \mathrm{O}_{4}$ was removed by magnetic decantation. The mother liquor was decanted and transferred to a new pressurized vial, followed by heated for additional $5 \mathrm{~h}$ at $140^{\circ} \mathrm{C}$. Yield of 1 did not substantially improve after the catalyst was removed, proving that leaching species if possible is negligible (Fig. 1). Notably, product 1 was obtained in $84 \%$ yield after $7 \mathrm{~h}$ if the magnetic copper oxide was not separated.

Furthermore, reusability of the copper ferrite is also investigated. The recovered $\mathrm{CuFe}_{2} \mathrm{O}_{4}$ nanoparticles were carefully 


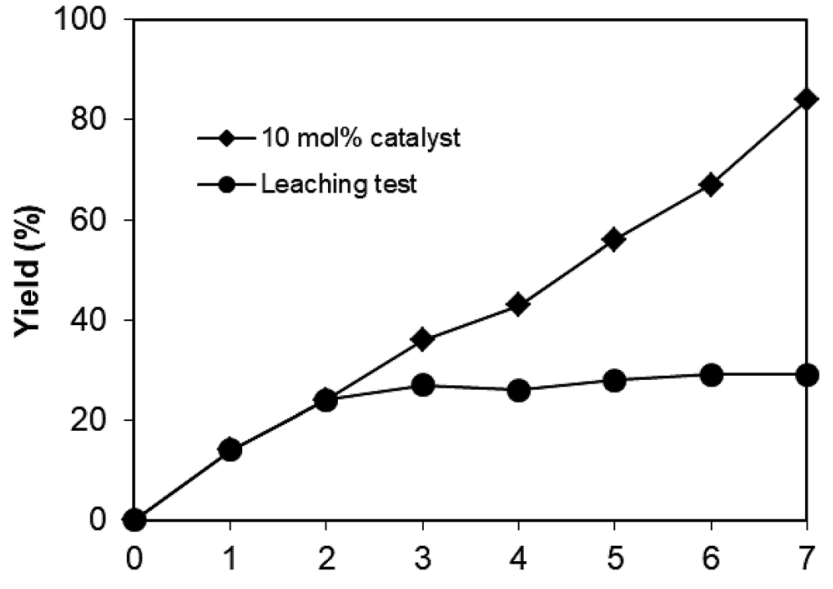

Time (h)

Fig. 1 Kinetic profile for the coupling of 2-aminopyrimidine with trans-chalcone in the presence of $\mathrm{CuFe}_{2} \mathrm{O}_{4}$. The circle-dot line represents the profile when $\mathrm{CuFe}_{2} \mathrm{O}_{4}$ was filtered after 2 hours.

washed with ethyl acetate, ethanol, and acetone. The copper ferrite was then heated at $120{ }^{\circ} \mathrm{C}$ under strong vacuum for $6 \mathrm{~h}$. The dried particles were then used for new catalytic reactions under standard conditions. The result shows that $\mathrm{CuFe}_{2} \mathrm{O}_{4}$ catalyst could be reused up to 5 times, while yield of the $5^{\text {th }}$ time run was still $81 \%$ (Fig. 2). Additionally, XRD analysis of the recovered $\mathrm{CuFe}_{2} \mathrm{O}_{4}$ revealed that the structure of the superparamagnetic nanoparticles was still maintained during the course of the reaction (Fig. 3).

It should be noted that the methods for direct synthesis of aroylimidazo[1,2-a]pyridines and aroylimidazo[1,2- $a]$ pyrimidines from 2-aminopyridines and 2-aminopyrimidines, respectively, are known. Some typical protocols are presented in Table 3. Until now, most of the methods still suffer from notorious challenges. For example, early works of Hajra or Kumar relied on the use of nonreusable catalyst $\left(\mathrm{CuCl}_{2}\right)$ and/or an external ligand

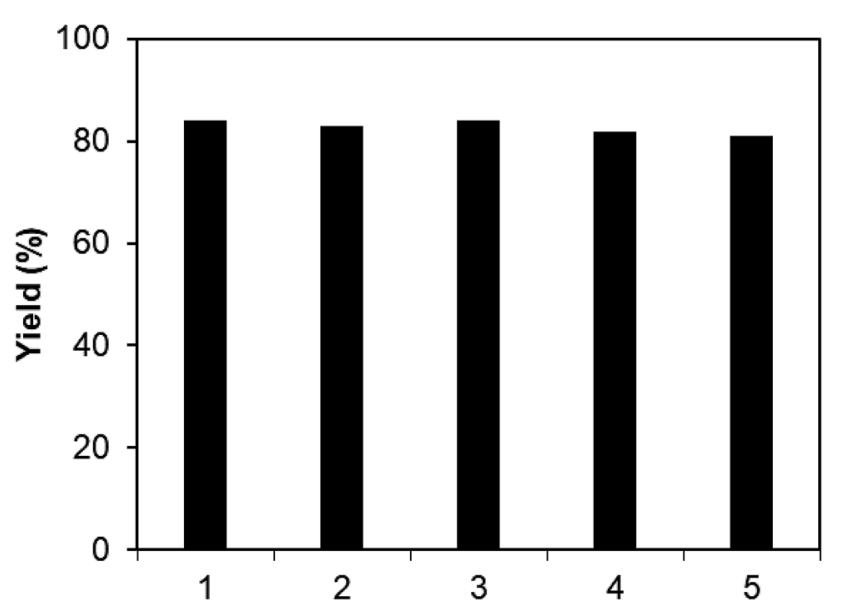

\section{Catalytic run}

Fig. 2 Reuse of copper ferrite for the coupling of 2-aminopyrimidine with trans-chalcone.

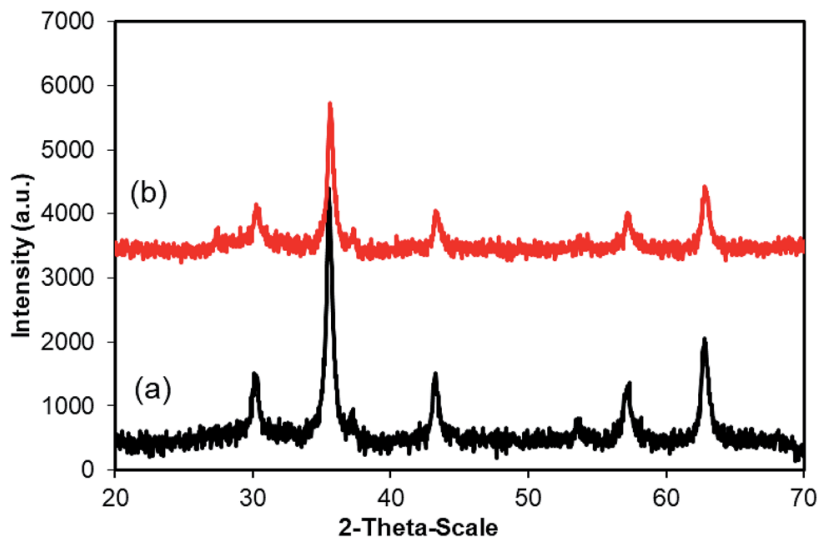

Fig. 3 XRD patterns of the fresh (a) and reused (b) $\mathrm{CuFe}_{2} \mathrm{O}_{4}$ for the coupling of 2-aminopyrimidine with trans-chalcone.

Table 3 Advantages and disadvantages of available methods for coupling of 2-aminopyridines/2-aminopyrimidines and chalcones

\begin{tabular}{|c|c|c|c|}
\hline Methods & Pros & Cons & Reference \\
\hline $\begin{array}{l}\mathrm{Cu}(\mathrm{OAc})_{2}+1,10- \\
\text { phenanthroline }\end{array}$ & Wide scope of substrates & $\begin{array}{l}\text { Requirement } \\
\text { of ligand } \\
\text { Nonreusable } \\
\text { catalyst }\end{array}$ & $3 a$ \\
\hline $\mathrm{CuCl}_{2}$ & Ligandless conditions & $\begin{array}{l}\text { Nonreusable } \\
\text { catalyst }\end{array}$ & $3 f$ \\
\hline $\mathrm{CuCl}_{2}+\mathrm{K}_{2} \mathrm{CO}_{3}$ & One pot reaction & $\begin{array}{l}\text { Excess } \\
\text { inorganic base }\end{array}$ & $3 e$ \\
\hline $\mathrm{I}_{2}+\mathrm{AlCl}_{3}$ & Wide scope of substrates & $\begin{array}{l}\text { Moisture } \\
\text { sensitivity }\end{array}$ & $3 g$ \\
\hline Our method & $\begin{array}{l}\text { Wide scope of substrates } \\
\text { Recoverable catalyst } \\
\text { No need of ligand } \\
\text { and/or base }\end{array}$ & & \\
\hline
\end{tabular}

(1,10-phenanthroline). ${ }^{3 a, 3 f}$ Later, Kumar developed an one-pot method for synthesis of 3-aroylimidazo[1,2-a]pyridines which employed the excess amount of inorganic base $\mathrm{K}_{2} \mathrm{CO}_{3} \cdot{ }^{3 e}$ Recently, a transition-metal-free protocol was also presented; however, the practicality of the method is still questionable since the procedure required the use of $\mathrm{AlCl}_{3}$ which is extremely moisture sensitive. ${ }^{3 g}$ Compared to the previous reports, our method would offer a possibility to prepare imidazo[1,2-a]pyridines towards green chemistry. The conditions use superparamagnetic $\mathrm{CuFe}_{2} \mathrm{O}_{4}$ nanoparticles, which are viably recoverable, for synthesis of fused $\mathrm{N}$-heterocycles in good yields and high compatibility of functional groups.

\section{Conclusions}

In conclusion, we develop a method for coupling of 2-aminopyridines or 2-aminopyrimidines with trans-chalcone to obtain aroylimidazo[1,2- $a]$ pyrimidines and aroylimidazo[1,2-a]pyridines. Reactions proceed in the presence of $\mathrm{CuFe}_{2} \mathrm{O}_{4}$ catalyst, two equivalents of iodine, and 1,4-dioxane solvent. Functionalities such as methyl, methoxy, chloro, bromo, and ester 
groups are compatible with reaction conditions. The catalyst is superior to many common copper or iron complexes. The superparamagnetic copper oxide nanoparticles is truly heterogeneous and reusable, up to 5 times, without a major loss of structure or activity. Our method for synthesis of fused Nheterocycles is useful for later studies towards sustainable chemistry.

\section{Conflicts of interest}

There are no conflicts to declare.

\section{Acknowledgements}

The Viet Nam National Foundation for Science and Technology Development (NAFOSTED) is acknowledged for supporting this research under Project code 104.05-2018.13 (for Nhan T. H. Le).

\section{References}

1 (a) Y. Volkova and V. Gevorgyan, Chem. Heterocycl. Compd., 2017, 53, 409; (b) C.-H. Ke, B.-C. Kuo, D. Nandi and H. M. Lee, Organometallics, 2013, 32, 4775; (c) A. Douhal, F. Amat-Guerri and A. U. Acuna, J. Phys. Chem., 1995, 99, 76; (d) B. Frett, N. McConnell, A. Kharbanda, G. Naresh, B. Rounseville, C. Warner, J. Chang, N. Debolske and H.-y. Li, Tetrahedron Lett., 2018, 74, 4592; (e) L. Almirante, L. Polo, A. Mugnaini, E. Provinciali, P. Rugarli, A. Biancotti, A. Gamba and W. Murmann, J. Org. Chem., 1965, 8, 305; (f) A. K. Bagdi, S. Santra, K. Monir and A. Hajra, Chem. Commun., 2015, 51, 1555; (g) H. G. O. Alvim, J. R. Correa, J. A. F. Assumpção, W. A. da Silva, M. O. Rodrigues, J. L. de Macedo, M. Fioramonte, F. C. Gozzo, C. C. Gatto and B. A. D. Neto, J. Org. Chem., 2018, 83, 4044; (h) Y. Shigemitsu, T. Mutai, H. Houjou and K. Araki, Phys. Chem. Chem. Phys., 2014, 16, 14388; (i) I. Luz, F. X. Llabrés i Xamena and A. Corma, J. Catal., 2012, 285, 285; (j) L. Jianchao and C. Qiyuan, Prog. Chem., 2010, 22, 631; (k) A. R. Harris, D. M. Nason, E. M. Collantes, W. Xu, Y. Chi, Z. Wang, B. Zhang, Q. Zhang, D. L. Gray and J. E. Davoren, Tetrahedron, 2011, 67, 9063; (l) Z. Wu, M. E. Fraley, M. T. Bilodeau, M. L. Kaufman, E. S. Tasber, A. E. Balitza, G. D. Hartman, K. E. Coll, K. Rickert, J. Shipman, B. Shi, L. Sepp-Lorenzino and K. A. Thomas, Bioorg. Med. Chem. Lett., 2004, 14, 909; (m) T. D. Penning, N. S. Chandrakumar, B. N. Desai, S. W. Djuric, A. F. Gasiecki, J. W. Malecha, J. M. Miyashiro, M. A. Russell, L. J. Askonas, J. K. Gierse, E. I. Harding, M. K. Highkin, J. F. Kachur, S. H. Kim, D. Villani-Price, E. Y. Pyla, N. S. Ghoreishi-Haack and W. G. Smith, Bioorg. Med. Chem. Lett., 2003, 13, 1137.

2 (a) H. Ilda, R. Demizu and R. Ohkado, J. Org. Chem., 2018, 83, 12291; (b) G. Kibriya, A. K. Bagdi and A. Hajra, Org. Biomol. Chem., 2018, 16, 3473; (c) U. B. Karale, S. Kalari, J. Shivakumar, V. B. Makane, D. A. Babar, R. P. Thakare, B. N. Babu, S. Choprad and H. B. Rode, RSC Adv., 2016, 6, 65095; (d) S. Lei, Y. Mai, C. Yan, J. Mao and H. Cao, Org.
Lett., 2016, 18, 3582; (e) Y. Wu, H.-R. Zhang, R.-X. Lin, Q. Lan and X. S. Wang, Adv. Synth. Catal., 2016, 358, 3528.

3 (a) K. Monir, A. K. Bagdi, S. Mishra, A. Majee and A. Hajra, Adv. Synth. Catal., 2014, 356, 1105; (b) G. Qian, B. Liu, Q. Tan, S. Zhang and B. Xu, Eur. J. Org. Chem., 2014, 4837; (c) J. Liu, W. Wei, T. Zhao, X. Liu, J. Wu, W. Yu and J. Chang, J. Org. Chem., 2016, 81, 9326; (d) D. Kour, A. Gupta, K. K. Kapoor, V. K. Gupta, D. Singh and P. Das, Org. Biomol. Chem., 2018, 16, 1330; (e) P. Kaswan, K. Pericherla, H. K. Saini and A. Kumar, RSC Adv., 2015, 5, 3670; (f) P. Kaswan, K. Pericherla, Rajnikant and A. Kumar, Tetrahedron, 2014, 70, 8539; (g) M.-M. Xing, M. Xin, C. Shen, J.-R. Gao, J.-H. Jia and Y.-J. Li, Tetrahedron, 2016, 72, 4201.

4 (a) S. Cacchi, A. Clogli, N. Demitri, G. Fabrizi, F. Ghirga, A. Gogglamani, A. Iazzetti and D. Lamba, Synthesis, 2018, 50, 3513; (b) J. Zeng, Y. J. Tan, M. L. Leow and X.-W. Liu, Org. Lett., 2012, 14, 4386; (c) S. Samanta and A. Hajra, Chem. Commun., 2018, 54, 3379; (d) X. Tian, L. Song, M. Wang, Z. Lv, J. Wu, W. Yu and J. Chang, Chem. - Eur. J., 2016, 22, 7617.

5 For review: (a) A. Fihri, M. Bouhrara, B. Nekoueisharaki, J.-M. Besset and V. Polshiettiwar, Chem. Soc. Rev., 2011, 40, 5181; (b) D. Wang and D. Astruc, Chem. Soc. Rev., 2017, 46, 816; (c) L. Liu and A. Corma, Chem. Rev., 2018, 118, 4981. Selected examples:; (d) F. Chen, B. Sahoo, C. Kreyenschulte, H. Lund, M. Zeng, L. He, K. Junge and M. Beller, Chem. Sci., 2017, 8, 6239; (e) D. Mateo, J. Albero and H. Garcia, Energy Environ. Sci., 2017, 10, 2392; (f) P.-H. Phua, L. Lefort, J. A. F. Boogers, M. Tristany and J. G. de Vries, Chem. Commun., 2009, 3747; (g) R. Hudson, C.-J. Li and A. Moores, Green Chem., 2012, 14, 622; (h) F. Chen, A.-E. Surkus, L. He, M.-M. Pohl, J. Radnik, C. Topf, K. Junge and M. Beller, J. Am. Chem. Soc., 2015, 137, 11718; (i) V. Iablokov, S. K. Beaumont, S. Alayoglu, V. V. Pushkarev, C. Specht, J. Gao, A. P. Alivisatos, N. Kruse and G. A. Somorjai, Nano Lett., 2012, 12, 3091; (j) J. Oliver-Messeguer, L. Liu, S. García-García, C. Canós-Giménez, I. Domínguez, R. Gavara, A. Doménech-Carbó, P. Concepción, A. LeyvaPérez and A. Corma, J. Am. Chem. Soc., 2015, 137, 3894.

6 For review: (a) S. Shylesh, V. Schünemann and W. R. Thiel, Angew. Chem., Int. Ed., 2010, 49, 3428; (b) K. V. S. Ranganath and F. Glorius, Catal. Sci. Technol., 2011, 1, 13. Selected examples:; (c) A. Ying, S. Liu, Z. Li, G. Chen, J. Yang, H. Yan and S. Xu, Adv. Synth. Catal., 2016, 358, 2116; (d) M. Afradi, N. Foroughifar, H. Pasdar and H. Moghanian, $R S C A d v$., 2016, 6, 59343; (e) S. Kaur, M. Kumar and V. Bhalla, Chem. Commun., 2015, 51, 16327; (f) F. M. Moghaddam, G. Tavakoli, A. Moafi, V. Saberi and H. R. Rezvani, ChemCatChem, 2014, 6, 3474; (g) J. Liu, X. Peng, W. Sun, Y. Zhao and C. Xia, Org. Lett., 2008, 10, 3933; (h) M. Li, B. Li, H.-F. Xia, D. Ye, J. Wu and Y. Shi, Green Chem., 2014, 16, 2680; (i) A. Hu, G. T. Yee and W. Lin, J. Am. Chem. Soc., 2005, 127, 12486; (j) X. Cui, W. Li, P. Ryabchuk, K. Junge and M. Beller, Nat. Catal., 2018, 1, 385. 7 (a) S. Vásquez-Céspedes, K. M. Chepiga, N. Möller, A. H. Schäfer and F. Glorius, ACS Catal., 2016, 6, 5954; (b) 
S. Vásquez-Céspedes, M. Holtkamp, U. Kast and F. Glorius, Synlett, 2017, 28, 2759; (c) G. Choudhan, D. Wang and H. Alper, Chem. Commun., 2007, 4809; (d) R. K. Sharma, Y. Monga, A. Puri and G. Gaba, Green Chem., 2013, 15, 2800; (e) R. K. Sharma, R. Gaur, M. Yadav, A. K. Rathi, J. Pechousek, M. Petr, R. Zboril and M. G. Gawande, ChemCatChem, 2015, 7, 3495; (f) Z.-L. Wang, RSC Adv., 2015, 5, 5563; (g) J. M. Pérez and D. J. Ramón, Eur. J. Org. Chem., 2016, 2016, 4354.
8 (a) P. T. Ha, O. T. K. Nguyen, K. D. Huynh, T. T. Nguyen and N. T. S. Phan, Synlett, 2018, 29, 2031; (b) C. K. Nguyen, N. N. Nguyen, K. N. Tran, V. D. Nguyen, T. T. Nguyen, D. T. Le and N. T. S. Phan, Tetrahedron Lett., 2017, 58, 3370; (c) C. K. Nguyen, H. H. Vu, H. V. Dang, N. N. Nguyen, N. T. H. Le and N. T. S. Phan, RSC Adv., 2017, 7, 55756; (d) O. T. K. Nguyen, L. T. Nguyen, N. K. Truong, V. D. Nguyen, A. T. Nguyen, N. T. H. Le, D. T. Le and N. T. S. Phan, RSC Adv., 2017, 7, 40929. 